\title{
Contradictions of a knowledge intensive economy. Interview with Michael Perelman, Professor at California State University
}

The text presents an interview with Michael Perelman, Professor at the Economics Department of California State University, Chico. The questions stimulate the interviewee to analyze the information age and especially some contradictions of the contemporary economy, which is supposed to be a knowledge intensive economy.

Key-words: Michael Perelman, information age, knowledge intensive economy, intellectual property rights.

Interviewer: Rodrigo Moreno Marques has a Master's Degree in Information Science from the Information Science School at UFMG (Brazil), where he is a doctoral candidate since 2010. During 2012 he was a research scholar at California State University, Chico.

Interviewee: Michael Perelman has a PhD Degree in Economics from University of California, Berkeley. Since 1971 he is professor of Economics at California State University, Chico.

\section{Contradictions of a knowledge intensive economy. Interview with Michael Perelman, Professor at California State University}

\begin{abstract}
For many affluent members of modern society, the mirage of a classless information age appears to be at hand. They have computers, on-line services, the Internet, cable modems, and the like. Certainly, one of the joys of our virtual reality is the privilege of choosing the world we want to see. (Michael Perelman)
\end{abstract}

\section{Introduction}

Michael Perelman has a PhD degree in Economics from University of California, Berkeley. Since 1971 he is professor of Economics at California State University, Chico.

On the last four decades Michael Perelman has published many books where he presents his unorthodox opinions about the contemporary world, emphasizing the critical point of view and the adoption of the 
lenses of the Political Economy. Among eighteen books published by the author, some address issues that are central in the field of Information Science, such as 'Information, Social Relations, and the Economics of High Technology' (1991), 'Class Warfare in the Information Age' (1998) e 'Steal This Idea: Intellectual Property and The Corporate Confiscation of Creativity' (2002).

On November 2012, Michael Perelman gave this interview. The questions deal with the universe of the information age and conduct Perelman to discuss many topics such as information and knowledge economy, the dynamics of knowledge and the challenges of education in the context of the current innovative and productive processes, the example of Silicon Valley and its connections with Asia, the contradictions of the information policies that unveil the strengthening of intellectual property rights and the panoptic control.

\section{Interview conducted on November 2012}

Interviewer: Many authors describe the emergence of the 'new economy', which is supposed to be driven by information and knowledge that flow through sociotechnical networks. In fact, what is going on? What does this trend mean for society as a whole?

Prof. Michael Perelman: What is new about the new economy is that people began to notice something that had been going on since the time when merchants first began bringing knowledge and information from the far-flung places where they were doing business. Some scholars would regard the telegraph as a greater step forward in the information revolution than the Internet, which obviously increased the bandwidth much more than the speed at which bits of information would flow. Regarding your question about predicting the trend, a famous baseball player, Yogi Berra, is reputed to have said that prediction is very difficult, especially for the future. For example, nobody seemed to have noticed that pornographers were creating the initial demand for both videos and books, which later became a staple of the Internet. The future will depend upon who is best able to muster the resources of the future. For example, the Arab Spring is often credited to social networking, at the same time that authoritarian governments (including my own) are able to gather intimate knowledge about virtually every aspect of our life. I fear that I might know the answer about which outcome will predominate.

Interviewer: It has been said that nowadays information and knowledge are commodities and are also stock in trade. Why the mainstream economic theories cannot be adopted to understand and explain the universe of the intangible commodities such as information and knowledge?

Prof. Michael Perelman: Information and knowledge make poor candidates for commodity status. First of all, economics assumes that people have sufficient knowledge to make intelligent choices about what 
they buy. In the case of information, once you have such knowledge you no longer have a need to purchase it. Also, for typical commodities, the consumer actually consumes them, such as would be the case in a piece of pie. With information and knowledge, its value does not degrade with use; it actually increases. Markets, however, are supposed to ration scarce goods. Once created, information and knowledge made scarce. In addition, markets are supposed to reward people according to their economic contribution. With information and ideas, disentangling the origin of information and ideas is virtually impossible. Think of any of the useful appliances that have become part of our lives - say, the light bulb, which Thomas Edison invented. The problem is that many other people were trying to perfect the same technology at the same time. All were building on prior knowledge and information. In perhaps the majority of great discoveries, numerous people or groups were working on the same project. For example, Newton and Leibniz were developing the calculus at the same time. Like a foot race in which the first person to cross the finish line is declared the winner. In the case of the calculus, Newton appointed the committee, which declared him the winner. Any great idea can be compared to a major river, which is fed by a number of tributaries. Scoop up a container of water and figure out how much credit each of the tributaries deserves for your water.

Interviewer: According to Robert Reich, the 'symbolic analyst' is a worker who has good skills to the current economy, where he is likely to occupy a privileged position. Reich describes the symbolic analyst as someone who is a problem identifier, a problem solver, or an innovator who can visualize new uses of existing technologies ${ }^{1}$. Is it possible to build an economy based mainly on symbolic analyst jobs, without the conflicts of material production?

Prof. Michael Perelman: Some firms are able to extract great wealth because of their place in the information sectors of the economy. Companies, such as Google or Apple, come to mind. One could easily get the impression that symbolic analysts somehow sit at their desk and conjure up their commodities. Google, however, depends upon huge amounts of coal dug from the bowels of the earth to power its servers. Apple's heavy use of underpaid young people in Chinese sweatshops is well-known. Also the company depends upon coltan from the Congo, where countless people have died fighting over access to this resource.

Interviewer: Since some decades ago, a new international division of labor is emerging, whereas the capital-intensive industries move to low-wage countries. Is it a good economic model for the United States to adopt the trend "designed in California, assembled in Asia", just like in the current Silicon Valley economy?

\footnotetext{
${ }^{1}$ REICH, R. The work of nations: preparing ourselves for 21st century. New York: Vintage Books, 1992.
} 
Prof. Michael Perelman: United States had a head start, helped, in large part by public support of its educational system - especially higher education. In recent years, the educational system has been starved while other countries around the world, such as Brazil, are hard at work developing theirs. We may be on the way to a world in which "designed in Brazil or China, assembled in the United States" might become the norm. You can see this happening in Asia today where Foxconn, Apple's main assembler, is beginning to produce its own products.

Interviewer: It has been said that the system supported by venture capitalists in Silicon Valley is better described as casino gambling than as an economic model. Do you agree with this argument?

Prof. Michael Perelman: Silicon Valley developed around Stanford University, where Frederick Terman was nurturing his best students will to create companies that would monetize their research. More important, Stanford University was a center of spending by the Department of Defense. Again, higher education became central in developing the new industry, which gave rise to Silicon Valley. In the beginning, the probability of a new startup being successful was high enough that some firms had a fairly consistent record of success. As the industry matured, the odds became less favorable - more casino-like.

Interviewer: A recent survey made with more than 600 global technology executives revealed that $43 \%$ of respondents say the tech innovation center of the world will move from Silicon Valley to another part of the world in next four years. China was named as the country most likely to be the next innovation center $(45 \%)$, followed by India $(21 \%)$ and Japan ( $9 \%)$ and Korea $(9 \%)^{2}$. This data suggests that the innovative knowledge is going abroad, following the outsourcing of the manufacturing plants. Does the national policies can drive the flow of knowledge in this context?

Prof. Michael Perelman: The Foxconn story is a good example of this. Information, research, and knowledge often follows manufacturing, which creates challenges that leads people to important breakthroughs. The symbolic analysts, in contrast, are more likely to just rearrange existing information. The name Reich gave them even suggests this limitation.

Interviewer: Does the US educational system need to be adapted for the challenges of the current economy?

Prof. Michael Perelman: The US educational system is being dismantled. It is underfunded. Business interests and political factions are

\footnotetext{
2 GARBOWSKI, C. KPMG 2012 Global Technology Innovation Survey. June 2012, Available at: http://bitpipe.computerweekly.com/detail/RES/1340802817_402.html (Accessed: 28th December 2012).
} 
attacking scholars and scientists, so much so that climate science and biology are matters of great controversy.

Interviewer: In 2002, in your book 'Steal this idea', you described the dangerous way of building the 'corporate science' in US. How you realize the contemporary science in US, ten years after that publication?

Prof. Michael Perelman: Corporatization of science continues unabated. No good will come from the dismantling of the educational system.

Interviewer: Some companies claim that US faces skill shortages in particular areas, such as high-tech, despite persistent high unemployment. Importing highly skilled workers and exporting highly skilled jobs through outsourcing are controversial policies. Does US in fact faces skill shortages in such areas? Who faces the biggest problem? Those companies or the workers?

Prof. Michael Perelman: This skill shortage is often exaggerated. Corporations design hiring requirements that would be impossible to meet. This manufactured shortage allows corporations to import highly skilled workers, who will work for a pittance. Obviously, bringing in lowwage workers benefits the companies at the expense of the domestic workers. Recently, The Wall Street Journal had an article about this subject. It found that a highly skilled factory worker, scientifically trained to run complex equipment makes less than a manager in McDonalds. No wonder they face a shortage.Workers would enjoy an advantage if business had to pay high wages. Because the shortage is not real, real wages have not improved.

Interviewer: According to Ellen Cushing, "All over the world, workers are paid pennies to do menial online tasks in a largely unregulated, multimillion-dollar industry. (...) It's called microtasking, and it works by outsourcing small, virtual tasks to an army of online workers, who then perform them for pennies" 3 . Ultimately, what is the most important contribution of the Internet and of the information technologies for the workers? New ways of exploitation or new conditions for emancipation?

Prof. Michael Perelman: Just as the Internet can be used for either shoring up the powers of autocratic governments or providing the means of resistance to the same governments, technology can be used to reinforce exploitation or providing workers with some means of resistance.

Interviewer: The present patent system encourages companies to engage in "patent races" in which they attempt to amass as many patents

CUSHING, E. Dawn of the Digital Sweatshop. East Bay Express. Oakland, August 2012. Available at: http://www.eastbayexpress.com/ebx/dawn-of-the-digital-

sweatshop/Content?oid=3301022\&showFullText=true (Accessed: 28th December 2012) 
as possible, aiming to dominate the market. In extreme cases, this process can lead to some kind of oligopoly or monopoly. Do you think the policies of the United States are appropriate to protect their economy from this kind of risk?

Prof. Michael Perelman: The irony is that the same companies who have used patents in order to create monopolies for themselves are now under attack by patent trolls who acquire patents from bankrupt companies in order to sue the monopolistic patent holders. Neither party is virtuous in any respect, making their litigation somewhat enjoyable, except that the enormous costs consumed in the process will be passed on to the public. On the other hand, the United States is trying to tie the hands of other countries with so-called "free trade" treaties that buying them to the ridiculous system in the United States.

Interviewer: Patents are supposed to provide rewards for those who engaged in innovation, but they also impose costs. The current patent system creates enormous uncertainly because a patent thicket and its resulting litigation reduces the extended value of new investments in technology. Do the policies concerning intellectual property rights provide a secure environment for the companies who invest on the development of new products and new ideas?

Prof. Michael Perelman: The word security that you use makes any answer very difficult. Powerful companies with high-powered legal systems have been relatively secure, except for the problems of the patent trolls. On the other hand, innovative individuals and small companies with underpowered legal teams often find that they are unable to protect their own claims to intellectual property.

Interviewer: According to your words, "The strengthening of intellectual property rights is perhaps the most pressing foreign policy track in the United States today, possibly even more than oil. The government's efforts go well beyond shoring up the legal rights of holders of intellectual property. (...) This is probably the central thrust of the foreign policy of the government of the United States". Is the strengthening of intellectual property rights a policy strong enough to keep the information and knowledge economy working in the US?

Prof. Michael Perelman: I suspect that the claims for intellectual property in the United States reflect a response to what seems to be an ebbing of the country's economic power. The center of intellectual property will gradually shift in the direction of rapidly developing countries. To the extent that that occurs, the United States may eventually become victim of extreme intellectual property claims of other countries. 
Interviewer: In your book 'Class warfare in the information age', published in 1998, you described the panopticism as the mass surveillance that was going on to collect information of people by companies and by the Government. Since then, this global trend seems to have expanded and new technologies were created, such as Deep Packet Inspection. Is it possible to revert this world tendency and revalue the principles of freedom of speech, privacy of life and privacy of communication in the Internet?

Prof. Michael Perelman: The recent exposure of the emails of David Petraeus, the head of the Central Intelligence Agency of the United States, seems to be proof enough that nobody can expect any right of privacy in this country. Worse yet, companies in the United States and Israel are marketing the tools of repression to some of the most dictatorial countries in the world. Given the kind of power that accrues to governments able to call upon their intellectual Panopticon, their power to challenge any resistance to such authority would seem to be very strong. A concerted effort of people around the world would be required in order to reverse this Panoptic abuse of power.

Interviewer: Thank you for the interview, which was very stimulant. We hope to have other opportunities to discuss your ideas.

\section{Suggested readings}

PERELMAN, Michael. Information, Social Relations, and the Economics of High Technology. New York: Macmillan, 1991.

. Class Warfare in the Information Age. New York: St. Martin's Press, 1998.

. Steal this idea. New York: Palgrave Macmillan, 2002.

. The Political Economy of Intellectual Property, Montly Review, New York, v.54, n.8, January 2003. Available at: http://monthlyreview.org/2003/01/01/the-political-economy-ofintellectual-property (Accessed: 28th December 2012).

- Intellectual Property Rights and the Commodity Form: New Dimensions in the Legislated Transfer of Surplus Value, Review of Radical Political Economics, v. 35, p.304-311, 2003. Available at: http://rrp.sagepub.com/content/35/3/304.short (Accessed: 28th December 2012).

. What Went Wrong: An Idiosyncratic Perspective on the Economy and Economics. Review of Radical Political Economics, n.20, p.1-10, February 2012. Available at: http://rrp.sagepub.com/content/early/2012/02/06/0486613411434398.fu II.pdf+html (Accessed: 28th December 2012). 